NOTES

\title{
BEYOND ECONOMIC THEORY: A MODEL FOR ANALYZING THE ANTITRUST IMPLICATIONS OF EXCLUSIVE DEALING ARRANGEMENTS
}

\author{
WANDA JANE ROGERS
}

\section{INTRODUCTION}

Contractual agreements requiring a supplier to deal exclusively with a single distributor frequently serve as the foundation for busmess distribution systems. Antitrust law rarely questions the legality of such exclusive dealing agreements, which often create inarket efficiencies at both the supplier and distributor levels. However, when exclusive dealing has as its purpose or effect the elimination of actual or potential competitors from the market, it falls squarely witlim the reach of the antitrust laws. This potential both to create efficiencies and to mluibit natural competitive forces has proven problematic for courts interpreting antitrust law and applying it to exclusive dealing arrangements.

The primary goal of antitrust law, as articulated both by Congress $^{1}$ and by the courts, ${ }^{2}$ is the promotion of competition in the marketplace. Congress's original intent in enacting the Sherman $\mathrm{Act}^{3}$ was the elimination of business combinations and other restraints of trade that created monopoly. ${ }^{4}$ Yet antitrust law tolerates monopoly that results from legitimate, competitive busmess

1. "[T] he object aimed at by this bill [the Sherman Act] is to secure competition of the productions of different States which necessarily enter into interstate and foreign commerce." 21 CONG. REC. S2462 (1890) (statement of Sen. Sherman).

2. See, e.g., Umited States v. E.I. Du Pont de Nemours \& Co., 351 U.S. 377, 386-87 (1956); Standard Oil Co. v. United States, 221 U.S. 1, 58 (1911); Umited States v. American Tobacco Co., 221 U.S. 106, 179 (1911).

3. 15 U.S.C. $\$ \S 1-7$ (1994).

4. 21 CONG. REC. S2456 (1890) (statement of Sen. Sherman). Since the original legislation was passed, however, courts have exercised their judicial authority to expand the Act's scope to reach a much broader range of anticompetitive conduct. The Sherman Act is recognized widely as a legislative command that the judiciary develop a common law of antitrust. Rudolph J. Peritz, A Counter-History of Antitrust Law, 1990 DUKE L.J. $263,269$. 
practices. ${ }^{5}$ The attempt to strike a balance between protecting competition and encouraging individual "industrial liberty" has led to contrasting views of antitrust law and policy.

Two primary and divergent economic views of antitrust have emerged. The first view is premised on the assumption that in any given industry, unarket forces eventually will erode artificial competitive restraints and dilute the accumulation of market power by private firms. The Chicago School embraces this idea. ${ }^{7}$ Proponents of the Chicago School model would limit the scope of antitrust law and policy to economic efficiency concerns and would eschew protection of small businesses. ${ }^{8}$ This limited scope, together with the belief that public intervention usually is not required to preserve competition in the marketplace, encourages courts to examine possible antitrust violations carefully only in extreme situations that clearly lead to market imefficiencies. ${ }^{9}$ The Chicago School, arguing that exclusive dealing generally is an efficient business practice with procompetitive effects, disapproves of close judicial scrutiny of exclusive dealing agreements and contends that courts should treat such agreements permissively. ${ }^{10}$

5. During Senate debate on the Sherman Act, Senator Sherman noted the importance of protecting legitimate business practices:

It is said that this bill [the Sherman Act] will interfere with lawful trade, with the customary business of life. I deny it. It aims only at unlawful combinations. It does not in the least affect combinations in aid of production where there is free and fair competition. It is the right of every man to work, labor, and produce in any lawful vocation and to transport his production on equal terms and conditions and under like circumstances. This is industrial liberty and hes at the foundation of the equality of all rights and privileges.

21 CONG. REC. S2455 (1890).

6. Id.

7. See, e.g., Robert H. Bork, THE ANTITRUST Paradox (1978); Richard A. POSNER, ANTTTRUST LAW: AN ECONOMIC PERSPECTIVE (1976).

8. See Herbert Hovenkamp, Antitrust Policy After Chicago, 84 MiCH. L. Rev. 213, 215 (1985) ("The Chicago School model of antitrust policy dictates that allocative efficiency as defined by the market should be the only goal of the antitrust laws."); BORK, supra note 7, at 7 ("A consideration of the virtues appropriate to law as law demonstrates that the only legitinate goal of antitrust is the maximization of consumer welfare. Current law lacks these virtues precisely because the Supreme Court has introduced conflicting goals, the primary one being the survival or comfort of small business.").

9. See Richard A. Posner, The Chicago School of Antitrust Analysis, 127 U. PA. L. REv. 925, 933 (1979). Posner notes that "[b]y 1969 . . . an orthodox Chicago position (well represented in the writings of Robert Bork) had crystallized: only explicit price fixing and very large horizontal mergers (mergers to monopoly) were worthy of serious concern."

10. See, e.g., BORK, supra note 7, at 303 ("Exclusive dealing, being a form of vertical integration, creates efficiencies and does not create restriction of output. It should, 
The second view is premised on a belief that private firms often distort natural market forces and that public intervention provides the appropriate cure for such distortion. This view recognizes that the antitrust laws should be used to pursue social and political goals other than efficiency, including the decentralization of accumulations of private economic power and the protection of consumers' freedom to inake choices in an open inarket. ${ }^{11}$ Proponents of this theory argue for closer judicial scrutiny of exclusivity agreements utilized to bar entry, facilitate anticompetitive collusion among firms, protect concentrated market power, or restrict entrepreneurial opportunity. ${ }^{12}$

Because exclusive dealing arrangements may have either proor anticounpetitive effects on market conditions, determining their legality in any given situation is a difficult task. While the divergent economic theories outlined above are useful in shaping analysis of exclusive dealing cases ${ }^{13}$ case-specific factual inquiries are required in order to reach results in accord with the purposes of the antitrust laws. Courts therefore must nove beyond a purely theoretical model and reduce economic abstractions to a inore practical level in order to determine the proper application of antitrust law and policy. Indeed, the true issue that arises in exclusive dealing cases is legal, not economic: Does the defendant exercise 1narket power in a manner that antitrust law seeks to avoid $?^{14}$ Consequently, the proper judicial approach to exclusive dealing is defined most effectively within the framework of a spe-

therefore, generally be lawful."); POSNER, supra note 7, at 205 ("[I]t is unlikely that a rational profit-maximizing firm will use exclusive dealing as a method of excluding a competitor.").

11. See Richard A. Posner, Will the Federal Courts of Appeals Survive Until 1984? An Essay on Delegation and Specialization of the Judicial Function, 56 S. CAL. L. REV. 761, 781 (1983).

12. See Kurt A. Strasser, Antitrust Policy in Agreeinents for Distributor Exclusivity, 16 CONN. L. REv. 969, 997 (1984).

13. The use of economic theory in these judicial determinations, however, has been the subject of wide debate. See, e.g., Eleanor M. Fox, The Politics of Law and Economics in Judicial Decision Making: Antitrust as a Window, 61 N.Y.U. L. REv. 554 (1986) (discussing the debate over the role of economic analysis in judicial decisionmaking). Compare Frank H. Easterbrook, Workable Antitrust Policy, 84 MiCH. L. REv. 1696 (1986) (defending the use of Chicago School economics in decisionmaking) with Eleanor M. Fox, Consumer Beware Chicago, 84 Mich. L. REv. 1714 (1986) (criticizing Chicago School economics analysis).

14. Thomas C. Arthur, The Costly Quest for Perfect Competition: Kodak and Nonstructural Market Power, 69 N.Y.U. L. REv. 1, 24-25 (1994). 
cific mdustry model, with a view toward the actual effects of exclusivity arrangements on competition within that industry.

This Note suggests a feasible judicial approach to exclusive dealing agreements by examining the competitive effects of exclusive dealing within a single industry: the computerized ticket distribution industry. An examination of the current controversy over the use of exclusive dealing within that industry is useful in defining a judicial standard in two ways. First, the structure and operation of the industry demonstrate the actual, as opposed to the theoretical, competitive effects of exclusive dealing in an industry in which market power is concentrated. Second, the ticketing service industry serves as an example of how exclusive dealing, in practice, can harm competitive forces, and when public intervention is required to promote or restore healthy competition. The consequences of exclusive dealing in this particular industry demonstrate why courts, in order to discern possible antitrust violations, must scrutinize exclusivity arrangements closely in any industry in which market power is concentrated.

Part I of this Note describes the infrastructure and operation of the computerized ticket distribution industry, which will serve as an example of how economic theory applies to market realities. Part II discusses basic economic theory and the possible pro- and anticoinpetitive effects of exclusive dealing contracts. This Part argues that an approach that contemplates an abstract nodel of efficiency, but moves beyond such a model and closely scrutinizes the actual anticompetitive effects of exclusive dealing is most likely to yield results im accord with the purposes of the antitrust laws. Part III then analyzes the historical judicial treatment of exclusive dealing and recent enforcement trends that further support close, case-specific judicial scrutiny of exclusive dealing agreements' actual effects on competition. After demonstrating how this framework for analysis apphies in the context of the ticket distribution industry, Part IV concludes that public intervention is required to curb anticompetitive business practices in that industry. This Part also demonstrates that in order to detect antitrust violations in any concentrated industry setting, courts must examine the use of exclusive dealing closely whenever anticompetitive effects are probable and market forces alone are unlikely to correct the situation. 


\section{THE STRUCTURE AND OPERATION OF THE COMPUTERIZED TICKET DISTRIBUTION INDUSTRY}

The computerized ticketing service industry is useful as a model because it displays actual inarket responses to exclusive dealing by a single dominant firm. Moreover, it is an industry that has led both disgruntled consumers and the government to question the legality of specific business practices undertaken by a powerful firm. Private plaintiffs have raised numerous claims against the industry's dominant firm, alleging various antitrust violations and demonstrating the actual impact exclusive dealing has on consumers. ${ }^{15}$ Public enforcement agencies also have taken an interest in industry practices. ${ }^{16}$ The state of competition within this industry illustrates the potential threat posed by exclusive dealing arrangements and shows why close judicial scrutiny of such arrangeinents is required to eliminate the concentration of market power and, ultimately, to protect consumers.

The dominant firm in the ticketing service industry is Ticketmaster. According to private plaintiffs, ${ }^{17}$ Ticketınaster attained its controlling position in the market through acquisitions of questionable legality and maintains its position by entering into uulawful exclusive dealing contracts with venues ${ }^{18}$ and event promoters. ${ }^{19}$ By binding a large portion of the available venues and

15. See, e.g., Ticketmaster Telemarketing Company Charged with Anticompetitive Conduct, 68 Antitrust \& Trade Reg. Rep. (BNA) 449 (Apr. 6, 1995); Sands v. TicketmasterNew York, 616 N.Y.S.2d 362 (N.Y. App. Div. 1994); Reynolds v. Bay Area Seating Serv., Inc., 1992 U.S. Dist. LEXIS 19282 (C.D. Cal. Nov. 9, 1992).

16. In 1994, the Department of Justice commenced an investigation into business practices in the industry. On July 5, 1995, the Antitrust Division closed its year-long investigation into Ticketnaster's contracting practices without taking further action. $D i$ vision Drops Investigation of Practices by Ticketmaster, 69 Antitrust \& Trade Reg. Rep. (BNA) 32 (July 13, 1995). In its statement, however, the Division warned that it would "continue to monitor conpetitive developments in the ticketing industry." Id. Apparently, the decision to drop the investigation was nuade on the grounds that new entry into the narket would counteract Ticketmaster's alleged anticompetitive activities. Id. However, no evidence of such entry has coine to light. IV.

17. For a factual examination of the allegations against Ticketunaster, see infra Part

18. The venues that inaintain contracts with Ticketmaster are typically large stadiums and arenas that host major entertainment events. This detail is important in defining the relevant market in which Ticketmaster operates. See infra text acconipanying notes 126-29.

19. In MovieFone, Inc. v. Ticketunaster Corp. (S.D.N.Y. March 17, 1995) (unpublished opinion), for example, the plaintiffs alleged that Ticketunaster acquired a $50 \%$ interest in the nation's largest supplier of autonated box office services, with whom 
promoters to exclusive dealing agreements, the firm allegedly denies actual and potential competitors access to the market and thereby suppresses natural competitive forces. These exclusivity arrangeinents represent both the mainstay of Ticketmaster's business operations and the crux of allegations of illegal business practices by the firm. ${ }^{20}$

The structure of the ticketing service industry is an important consideration in evaluating the impact of exclusive dealing arrangements on competition within the industry. Ticketing service coinpanies serve essentially as distributors of a supplier's (venue's and promoter's) product-that is, tickets to see entertainment events. The industry provides a service designed to enhance convemience to the consumer-purchasers of these tickets: Computerized ticket distribution allows consumers to buy tickets at local outlets and over the telephone, and to avoid waiting in long lines at a venue's box office. The ticketing company derives its revenues from a service charge added to the price of each ticket. ${ }^{21}$ When a

plaintiffs originally had a contract for the provision of computerized ticketing services. By acquiring this interest, Ticketınaster was able to exercise management control over the company and abrogated the 1992 contract with the plaintiffs. As a result, the plaintiffs were unable to enter the market for the sale of tickets to large-scale entertainment events. See Ticketmaster Teleticketing Company Charged, supra note 15. The plaintiffs further alleged that over a 10-year period, Ticketmaster has acquired 14 actual or potential competitors. Id.

20. Plaintiffs have alleged violations of both federal and state antitrust laws against Ticketmaster under a variety of theories. See Kevin E. Stern, The High Cost of Convenience: Antitrust Law Violations in the Computerized Ticketing Services Industry, 16 HASTINGS COMM. \& ENT. L.J. 349, 358 (1994). Allegations include conspiracy to fix prices, conspiracy to raise prices to finance illegal rebate schemes, and the illegal exercise of monopoly power. See id.; Robert Nolin, Should the Nation's Courts Scalp Ticketmaster?, THE RECORDER, July 21, 1994, at 3. This Note, however, will focus on Ticketmaster's alleged use of exclusive dealing contracts to restrain trade unreasonably in violation of $\S 1$ of the Sherman Act. Section 1 provides: "Every contract, combination in the form of trust or otherwise, or conspiracy, in restramt of trade or commerce among the several States, or with foreign nations, is declared to be illegal." 15 U.S.C. \& 1 (1994).

Exclusive dealing also may be analyzed as an exclusionary practice used to maintain a monopoly. Section 2 of the Sherman Act punishes "[e]very person who shall monopolize, or attempt to monopolize, or combine or conspire with any other person or persons, to monopolize any part of the trade or commerce . ..."15 U.S.C. \& 2. The importance of framing the issue as a $\S 2$ claim as opposed to a $\S 1$ claim may be in the remedy: a $\S 2$ claim of monopoly could result in dissolution of the firm, while a successful $\S 1$ claim would result in a conduct remedy, for example, shorter duration for contracts. Although some plaintiffs have raised $\S 2$ monopoly claims against Ticketmaster, the precise issues mvolved in evaluating these claims are beyond the scope of this Note.

21. See Stern, supra note 20 , at 350 . Service charges vary according to the particular 
ticketing service company contracts with a venue to distribute its tickets, the consumer can avoid paying these additional charges only by circumventing the ticketing company completely and purchasing a ticket directly at a venue box office. ${ }^{22}$

Ticketing service companies do not compete directly for consumers' busmess. Instead, they compete to secure contracts with venues and event promoters for the right to sell tickets to various entertainment events. Ticketing companies generally inake fixed payments to venues and promoters in exchange for the right to sell tickets; these compamies also may provide additional incentives to enter into such contracts by giving venues and promoters a percentage of the service charges paid by consumers..$^{23}$ Industry contracts generally grant the ticketing company the exclusive right to sell tickets off-site ${ }^{24}$ for all events sponsored by the venue or promoter, precluding the venue or promoter from using any other ticketing services for the duration of the contracts. These contracts typically last a term of three to five years. ${ }^{25}$ Exclusivity clauses form the primary. foundations for the relationship between ticket distributors and their supphers. ${ }^{26}$

Exclusive dealing arrangeinents have created a umique infrastructure within the ticketing service industry that has prompted consumers to question the legality of Ticketinaster's busiuess practices. The primary concern is that exclusive dealing contracts unreasonably restrain the supply of inputs (venues' tickets and promoters' services) available to rival ticketing service compamies, thereby giving Ticketınaster power to raise prices in the output inarket (ticket sales to consumers). ${ }^{27}$ Specifically, consumers have

event, facility, and method of purchase; these fees can increase the price of a ticket by $20 \%$ to $44 \%$ of the original face value. Id. at 353 .

22. Id. at 353 .

23. See Nolin, supra note 20 , at 3 .

24. The venue typically retains the right to sell its own tickets from the box office at the location of the venue itself. However, venue sales arrangements can vary, and tickets often sell out over the telephone before the box office opens for sales. See infra text accoinpanying notes 131-32.

25. See Nolin, supra note 20 , at 3 (reporting a three-year contract between Ticketmaster and the Centroplex, an arena in Orlando, Florida, and a five-year contract between Ticketmaster and the West Palın Beach Auditorium); Anthony Ramirez, Ticketmaster's Mr. Tough Guy, N.Y. TIMES, Nov. 6, 1994, at C1 (referring to a five-year contract between Ticketmaster and Meadowlands arena in New Jersey).

26. See Stern, supra note 20, at 353 ("The foundation of the computerized ticketing service business is the exclusive dealing agreement.").

27. See Thonas G. Krattenınaker \& Steven C. Salop, Anticompetitive Exclusion: Rais- 
alleged that Ticketmaster's exclusive dealing arrangements foreclose access by other ticketing companies to a large percentage of the venues and promoters necessary to hold major entertainment events. ${ }^{28}$ Consumers contend that by unreasonably excluding actual and potential competitors from a necessary source of demand for their services, Ticketınaster increases its market power. ${ }^{29}$ This conduct erodes competitive forces and allows Ticketmaster to exercise greater control over prices im the market and to raise ticket service charges to exorbitant amounts.

Consumers also have questioned Ticketmaster's practice of niducing promoters and venues to enter into exclusive contracts by sharing a percentage of the service charges with thein. ${ }^{30}$ This

ing Rivals' Costs To Achieve Power over Price, 96 YALE L.J. 209, 224 (1986). Labelling ticketing service companies as distributors, and venues and proinoters as suppliers may be a somewhat artificial construction. Exclusive dealing may refer both to contracts that require a distributor to deal solely with a single supplier and to contracts that restrict a supplier to a single distributor. Some commentators have treated the costs and henefits associated with these two categories of exclusive dealing separately. See Strasser, supra note 12 , at $970-71$. However, Krattenmaker and Salop demonstrate that the difference is not relevant to the analysis of anticompetitive exclusion: "To assess claims of anticonpetitive exclusion, the proper question is not which firm is a buyer and which a seller, but whether one (or both) is the purchaser of an exclusionary right that raises rivals' costs and gives the purchaser power over price in its market." Krattenmaker \& Salop, supra at 226. This Note analyzes exclusive dealing as a general category of exclusionary conduct.

28. See, e.g., Stern, supra note 20, at 358-59 (discussing California plaintiffs' allegations of Ticketinaster's violations of state antitrust laws, including restraint of trade and unreasonable foreclosure of competitors); see also Memorandum from Pearl Jam to the Antitrust Div. of the U.S. Dep't of Jnstice Concerning Anticompetitive Actions Engaged in by Ticketinaster Holdings Group Ltd. 11-12 (May 6, 1994) (on file with author) (alleging that Ticketmaster's enforcement of exclusive dealing agreemeuts forecloses access to "a significant percentage of the suppliers of services necessary to hold entertainment events").

29. Market power may be defined simply as the ability to control prices or exclude competitors. See, e.g., United States v. E.I. Du Pont de Nemours \& Co., 351 U.S. 377, 391 (1956).

30. See Stern, supra note 20 , at 358 (discussing plaintiffs' allegation that Ticketinaster has made payments of "secret rebates" to venues and promoters in order to attain exclusive dealing contracts). Critics have referred to this practice as providing "kickbacks." See Laurie P. Cohen, A White Shoe Firm, a Rock Band, and a Threat, WALL ST. J., July 29, 1994, at B1. This practice is not in itself a basis for antitrust liability; indeed, it may be a legitimate form of price competition that simply reflects the price the ticketing company is willing to pay for the exclusivity agreement. However, while this may he true in theory, the practice may, in effect, facilitate Ticketmaster's dominant position and its ability to raise prices to supracompetitive levels. See Stern, supra note 20, at 354 ("Since the agreements are exclnsive, the ticketing service is able to finance this fee-splitting scheme by charging higher convenience fees to the public without fear of losing business."). 
practice allegedly thwarts other ticketing service companies' efforts to compete with the incumbent firm, potentially mjuring the business of competitors and making entry by new firms extremely difficult. ${ }^{31}$ Moreover, the practice of sharing a portion of service charges raises questions about the venues' and promoters' actual motives for entering imto exclusive arrangements. Revenue-sharing gives these entities a vested interest in Ticketmaster's efforts to raise service charges. ${ }^{32}$

These business practices warrant especially close scrutimy when considered in the context of an industry reality: the imdisputable dominance of Ticketmaster in the market for ticket sales. ${ }^{33}$ Ticketmaster has no real competitors on a national scale. Since the acquisition of the assets of its only national competitor, Ticketron, in $1991{ }^{34}$ only small regional distributors independently market tickets. ${ }^{35}$ The nationwide predominance of a single firm $\mathrm{m}$ the ticketing service industry is sufficient $\mathrm{m}$ itself to raise suspicions concerning the legahty of its exclusivity arrangements, and, more generally, the vitahity of competition in the industry. ${ }^{36}$

31. During the 1980s, Ticketmaster reportedly was successful in luring business away from Ticketron, a major national rival, largely by promising venues and promoters a greater percentage of service charges. See Stern, supra note 20, at 354-55. Ticketmaster eventually acquired a majority of Ticketron's assets in 1991; the mevitable result was an increase in service fees for tickets. See id.

32. The issue of venue and promoter conduct is primarily relevant with respect to claims brought under a theory of couspiracy to monopolize under $\$ 2$ of the Sherman Act. However, their motives also may have an impact on the analysis of vertical restraints of trade under § 1 . See infra text accompanying notes 173-74.

33. See Nolin, supra note 20 , at 3 (reporting that Ticketmaster is "by far the largest distributor of tickets in the United States," with sales of 52 million tickets for a face value of $\$ 1.3$ billion and revenues of $\$ 190$ million in 1993).

34. The Justice Department swiftly approved Ticketmaster's 1991 buyout of Ticketron, despite protests by numerous cousumer groups, reportedly on the basis of the "failing firm" doctrine. See Stern, supra note 20, at 356 n.37. The three requirements of this doctrine are

(1) [t] he allegedly failing firm probably would be unable to meet its financial obligatious in the near future; (2) it probably would not be able to reorganize successfully under Chapter 11 of the Bankruptcy Act; and (3) it has made unsuccessful good faith efforts to elicit reasonable alternative offers of acquisition ... that would both keep it in the market and pose a less severe danger to competition than the proposed merger.

U.S. Department of Justice Merger Guidelines-1984, 4 Trade Reg. Rep. (CCH) q 13,103, at 20,567 (1988). Ordinarily, a firm must be in "critical condition" to pass this test. See United States v. Syufy Enterprises, 903 F.2d 659, 673 n.24 (9th Cir. 1990).

35. See Stern, supra note 20 , at 355 .

36. The primary threat exclusive dealing poses to competitors is its potential to exclude competitors and thereby imcrease nuarket power. See U.S. Healthcare, Inc. v. 


\section{The Competitive EFFects of EXClusive DeAling}

One type of exclusive dealing occurs when a firm contracts with a supphier for the suppher's agreement not to deal with the purchasing firm's competitors. ${ }^{37}$ Although both courts and commentators have scrutinized the use of exclusive dealing arrangements, they recognize that such arrangements are utilized widely and have the potential to promote competition as well as to suppress it. ${ }^{38}$ Analysis of both the pro- and anticompetitive effects of exclusivity agreements demonstrates how economic theory applies in the context of an actual imdustry setting and why a detailed factual inquiry into actual competitive effects is necessary.

\section{A. Potential Procompetitive Effects of Exclusive Dealing Arrange- ments}

Exclusive dealing often serves as a benign method for facihtating distribution, yielding benefits both to the businesses involved and to the consumer. Exclusive dealing potentially minimizes the cost and risk of conducting busimess in uncertam markets, which, in turn, increases operating efficiencies and decreases costs to the consumer ${ }^{39}$ In Standard Oil Co. v. United States, ${ }^{40}$ the leading case on exclusive dealing contracts, the Supreme Court described a number of ways in which exclusive dealing facilitates distribution and minimizes costs and risks. The Court stated that exclusive dealing contracts

may well be of economic advantage to buyers as well as to sellers, and thus indirectly of advantage to the consuming public. In the case of the buyer, they may assure supply, afford protection against rises in price, enable long-term planning on the basis of known costs, and obviate the expense and risk of storage in the quantity necessary for a commodity having a fluctuating demand. From the seller's point of view, [they] may make possible the

Healthsource, Inc., 986 F.2d 589, 595 (1st Cir. 1993); see also infra text accompanying notes 136-58. A firm's possession of a significant amount of market power, coupled with the use of exclusive dealing contracts, suggests that the firm's dominance is the result of restrictive exclusive dealing arrangements, not natural market forces.

37. See Krattenmaker \& Salop, supra note 27, at 215.

38. See, e.g., Tampa Electric Co. v. Nashville Coal Co., 365 U.S. 320 (1960); Standard Oil Co. v. United States, 337 U.S. 293 (1949) [hereinafter Standard Stations]; Strasser, supra note 12 , at $972-74$.

39. See Standard Stations, 337 U.S. at 306; see also Strasser, supra note 12, at 969.

40. 337 U.S. 293 (1949). The case is commonly referred to as Standard Stations. 
substantial reduction of selling expenses, give protection against price fluctuations, and ... offer the possibility of a predictable market. ${ }^{41}$

When exclusive dealing reduces costs and facilitates distribution in this manner, it creates market efficiencies that confer benefits to the ultimate consumer. ${ }^{42}$

A primary benefit of exclusive dealing contracts is a reduction in transaction costs. By entering into long-term contracts, both the suppher and the distributor are able to avoid the expense of reaching a new agreeinent for each individual transaction in a business relationship. In the ticketing service industry, for example, venues and ticketing companies are spared the costs of making arrangeinents for each entertainment event. Venues are able to simplify and facilitate ticket distribution by utilizing only a single source for tickets, and ticketing compamies are spared the uncertainty, and consequently the cost, of obtaiming an assured supply of entertainment events. ${ }^{43}$ Moreover, exclusive dealing inay lower transaction costs and facilitate distribution simply by building a positive relationship between the parties to the exclusive arrangement-promoting trust, loyalty, and the exchange of information. ${ }^{44}$

Exclusive dealing contracts also may allow businesses to circumvent the additional costs of free-riding by other firms. ${ }^{45}$ The problems of free-riding inay be explained as follows:

Exclusive dealing is sometimes needed to ensure that the beneflts generated by a capital investment in a particular brand of a product accrue to the party making that investment. In the ab-

41. Standard Stations, 337 U.S. at 306-07 (citation omitted). The Court here was describing requirements contracts, which are contracts that provide that a buyer will purchase all of its needed supply from the seller. For the purposes of this Note, requirements contracts and exclusive dealing are analytically identical.

42. See id. at 306.

43. See Krattenmaker \& Salop, supra note 27, at 228-29.

44. Strasser, supra note 12, at 973 (noting that exclusivity may successfully "creat[e] an identity of interest between supplier and distributor").

45. A recent case, Eastman Kodak Co. v. Image Technical Serv., 504 U.S. 451 (1992), see infra text accoinpanying notes 99-109, provides an example of how free-riding might serve as a justification for exclusive dealing. Kodak mamtained exclusivity agreements with parts supphers with whom Kodak necessarily shared technological information. Arguably, exclusivity provided a means for Kodak to prevent the unauthorized disclosure of information to its competitors, and thus to prevent competitors from free-riding by taking advantage of such technology. 
sence of exclusive dealing, coinpeting brands can free-ride on certain types of capital investınents and thereby rednce or destroy the incentive to make such investinents. Both consumer welfare and competitive processes can thereby be harmed. ${ }^{46}$

In order to justify the use of exclusive dealing contracts, firms thus may argue that exclusivity is necessary to eliminate potential freeriders. Although this argument is persuasive, less restrictive alternatives for avoiding the costs associated with free-riding frequently exist. $^{47}$

\section{B. Potential Anticompetitive Effects of Exclusive Dealing}

Although the potential procoinpetitive effects of exclusive dealing should not be ignored, exclusive dealing arrangements can have serious anticompetitive effects as well. The U.S. Court of Appeals for the First Circuit identified in U.S. Healthcare, Inc. v. Healthsource, Inc. ${ }^{48}$ the primary danger that exclusive dealing poses to competition: "[A]n exclusive arrangement may 'foreclose' so much of the available supply or outlet capacity that existing competitors or new entrants may be limited or excluded and, under certain circumstances, this may reinforce narket power and raise prices for consumers." ${ }^{49}$ The primary concern, then, is that exclusive dealing (a) will foreclose existing competitors, and (b) will erect entry barriers to deter potential competitors, thereby harming the ultimate consumer..$^{50}$

Foreclosure of existing competitors occurs when, for example, an exclusive dealing contract provides that certain supphers are to transact only with a single distributor; competitors of that suppher thereby are foreclosed from the demand represented by the contracting supphiers for the term of the contract. ${ }^{51}$ All contractual agreements result in some degree of foreclosure because a certain amount of demand necessarily disappears from the market when any contract is formed. Antitrust law is not concerned with this (1991)

46. Gregg Frasco, exclusive dealing: A Comprehensive Case Study 4

47. An example of a less restrictive alternative is a contractual term requiring confidentiality of technological or proprietary information exchanged between the supplier and distributor.

48. 986 F.2d 589 (1st Cir. 1993).

49. Id. at 595 .

50. See Strasser, supra note 12 , at 984 .

51. See FrASCO, supra note 46 , at 15. 
minimal foreclosure. It is concerned, however, with the possibility that effective foreclosure of a substantial amount of the market will have a negative impact on competition by increasimg inarket power and by enhancing the ability of imcumbent firms to raise prices to supracompetitive levels. Substantial market foreclosure is "one of the primary anticompetitive effects with which antitrust courts have been concerned." 52

Many commentators have argued that effective foreclosure never can occur because exclusive dealing arrangements that tie up a large number of supphers simply create demand for new supphier resources. This prompts new firms to enter the market and to provide a needed supply for the distributor's competitors (actual and potential), thereby enhancing competition. ${ }^{53}$ Advocates of this view further contend that exclusivity does not result in distributors' ability to raise prices to supracompetitive levels in the output market because competition for the business of the suppher firms will itself keep prices at a competitive level. ${ }^{54}$ However, these arguments ignore the anticompetitive effects of entry barriers, which exclusive dealing often builds and maintains as a bar to effective competition.

An "entry barrier" is any market condition that allows an incumbent firm to raise prices while deterring outsiders from entering the market. ${ }^{55}$ Exclusive dealing agreements erect entry bar-

52. Strasser, supra note 12 , at 986 . Strasser further notes two characteristics of exclusive dealing arrangements that are particularly conducive to market foreclosure. First, such agreements directly restrict competitors' access to certain suppliers or distributors. Second, such agreements tend to tie up the most efficient suppliers or distributors first, leaving only those of lesser quality and of lesser effectiveness available to competitors. See id. at 986-87. For further discussion of foreclosure see infra text accompanying notes 144-66.

53. See BORK, supra note 7, at 299-309; FRASCO, supra note 46, at 15-17; Strasser, supra note 12, at 987 (citing authorities).

54. See FrASCO, supra note 46, at 15-17. Frasco explains the argument as follows: "Supracompetitive pricing in the output market by [distributors] implies that existing rivals or entrants in the output market can offer existing and/or potential input suppliers a better deal. Hence entry would tend to take place in the output market and output prices would tend to fall." Id. at 17.

55. The term "entry barrier," actually has been defined in various, sometimes contrasting ways. For example, Joe Bain defines entry barriers as a measure of the extent to which an established firm is able to "elevate [its] prices above the minimized or competitive average costs of production and distribution" without "inducing new sellers to enter the industry." JOE S. BAIN, INDUSTRIAL ORGANIZATION 237 (1959). In contrast, George Stigler defines entry barriers as production costs "which must be borne by a firm which seeks to enter an industry but is not borne by firms already in the industry." 
riers by increasing the costs of entry and reducing the opportunity for potential competitors to gain access to a needed supply. ${ }^{56}$ As a result, exclusive dealing contracts may preserve or augment the market power of incumbent firms and create an anticounpetitive business environment. ${ }^{57}$

The final results of foreclosure and entry barriers are higher costs to the consumer and, in extreine cases, a lack of any real freedom to choose which products she will purchase. In the ticketing service indnstry, for example, market foreclosure allegedly has forced consumers to purchase tickets through a single distributor and to pay that distributor's inflated price..$^{58}$ Commentators have noted that the "protection of the freedom of buyers to make uncoerced choices in an unrestricted inarket was a primary concern of Congress" 59 in enacting antitrust legislation and is "a fundamental policy in distributor exclnsivity cases." ${ }^{" 60}$ Moreover, the Supreme Court expressly recognized the importance of this freedom in FTC v. Brown Shoe Co. ${ }^{61}$ Therefore, in the absence of compelling and demonstrable efficiency justifications, antitrust law recognizes that exclusive dealing arrangements result in foreclosure and entry barriers that in turn ultimately liarm the consumer. ${ }^{62}$

GeORge J. StIGLER, The ORganization OF Industry 67 (1968). Professor Hovenkamp notes that most antitrust analysis focuses primarily on the "Bainian" rather than the "Stiglerian" approach to entry barriers. See HERBERT HOVENRAMP, FEDERAL ANTITRUST POLICY: THE LAW OF COMPETITION AND ITS PRACTCE 40 (1994). But see In re Echlin Mfg. Co., 105 F.T.C. 410, 483-87 (1985). This distinction is subtle; the simple definition used in the text is sufficient for an understanding of the present discussion.

56. See In re Beltone Electronics Corp., 100 F.T.C. 68, 197-218 (1982).

57. See id. Entry barriers will be discussed in greater detail infra Section IV (C).

58. See supra text accompanying notes 27-30.

59. Strasser, supra note 12, at 992.

60. Id. See also Baddia J. Rashid, Antitrust Aspects of Exclusive Dealing Arrangements, 40 GEO. L.J. 241, 254-56 (1952).

61. 384 U.S. 316 (1966). The Court determined that the practice at issue was at odds with "the central policy of both $\S 1$ of the Sherman Act and $\S 3$ of the Clayton Act against contracts which take away freedom of purchasers to buy in an open narket." Id. at 321.

62. See Strasser, supra note 12, at 992. Strasser argues that the goal of providing uncoerced choices is "not a useful analytical concept for deciding distributor exclusivity cases." Id. The present discussion does not purport to utilize consumer freedom as an analytical tool; lack of freedoin is recognized here simply as the unfortumate result of anticonıetitive narket forces. 


\section{The Debate over the Proper Treatment of Exclusive Dealing Arrangements}

Two basic, divergent views of antitrust law generally and exclusive dealing specifically have evolved. The first approach would treat exclusive agreements as presumptively legal. ${ }^{63}$ The Chicago School advocates this position, focusing primarily on the procompetitive effects of exclusivity and other categories of vertical restraints. ${ }^{64}$ This extreme approach rehes heavily on pure economic theory ${ }^{65}$ and assumes that market processes eventually will erode privately imposed competitive restraints and narket power. ${ }^{66}$ Chicagoans argue that market forces alone usually can achieve coordination in distribution at the least cost. ${ }^{67}$ Such strict analysis, however, often fails to take into account actual market conditions or to recognize that economic models must account for market imperfections: "[M] arkets do not always coordinate transactions or minimize costs perfectly." al variations from ideal market conditions mevitably leads to inac-

63. See, e.g., Henry N. Butler \& Barry D. Baysinger, Vertical Restraints of Trade as Contractual Integration: A Synthesis of Relational Contracting Theory, Transaction-Cost Economies, and Organization Theory, 32 EMORY L.J. 1009, 1014 (1983).

64. Advocates of this view further argue that "vertical restraints are merely a category of generic business practices that may enhance economic efficiency through a partial suppression of inarket forces. The efficiency-enhancing aspects of these business practices indicate that a proper antitrust policy should incorporate a strong, yet rebuttable, presumption of their legality." Id.

65. Judge Posner has argued: "Casual observation of business behavior, colorful characterizations (such as the term "barrier to entry"), eclectic forays into sociology and psychology, descriptive statistics, and verification by plausibility [have taken] the place of the careful definitions and parsimonious logical structure of econoumic theory." Posner, supra note 9 , at 929.

66. The idea that market forces alone will expunge anticoinpetitive behavior, however, stands in direct contrast to the purpose of the original enactment of antitrust laws: The Sherman Act reflects a poincy that we are unwilling to wait for the cure. See National Association of Attorneys General, 1995 Revisions to the Vertical Restraints Guidelines, in 68 Antitrust \& Trade Reg. Rep. (BNA) 409, 435 (1995).

67. See Strasser, supra note 12, at 969 (citing ADAM SMTrH, The WeAlTH of NATIONS (R. Campbell et al. eds., 1981)).

Also fundamental to Chicago school thinking is a distrust of the ability of the legal system to correct perceived competitive harms and in the courts' capacity to distinguish antitrust law from policy preferences, without focusing on efficiency concerns. For a useful discussion of the efficacy of the legal system in antitrust, see Thomas C. Arthur, The Costly Quest for Perfect Competition: Kodak and Nonstructural Market Power, 69 N.Y.U. L. REV. 1, 18-19 (1994).

68. Strasser, supra note 12, at 969. 
curate results in interpretation and application of the antitrust laws. ${ }^{69}$

The opposing view advocates close scrutiny of potentially anticompetitive business practices, including exclusivity arrangements, on grounds that incumbent firms do not require the support of severe distribution restraints and that less restrictive alternatives are frequently available. ${ }^{70}$ This view, generally premised on the theory that markets are delicate and prone to distortion by individual firms, contends that public intervention is the appropriate remedy for such problems. ${ }^{71}$ Although proponents of this approach recognize that exclusive dealing can in fact lead to more efficient and cost-effective distribution of goods by allowing a distributor to coordinate transactions herself, ${ }^{72}$ they also argue that exclusive dealing should be prohibited when it is used to foreclose actual or potential competitors, protect market power, or restrict entrepreneurial opportunity. ${ }^{73}$

The argument that competition is never harmed by exclusive dealing $^{74}$ tends to ignore or dismiss the theoretical and, more importantly, the actual anticompetitive effects of exclusivity arrangements. Chicago School economic theory inandates that the antitrust laws protect only efficiency; ${ }^{75}$ at times, the Supreme Court has followed this approach and has failed to balance economic theory with antitrust pohicy. ${ }^{76} \mathrm{~A}$ theory that holds efficiency to be the sole purpose of antitrust law overlooks the original intent

69. See Arthur, supra note 67, at 8 ("In short, the [perfect competition] model leaves out the factors which provide for economic progress. These factors . . must be kept in mind if antitrust regulation is to reach sensible results.").

70. See In re Beltone Electromics Corp., 100 F.T.C. 68, 205 (1982).

71. See id.

72. See Strasser, supra note 12, at 969.

73. See id. at 997 .

74. See Butler \& Baysinger, supra note 63 , at $1087-88$.

75. See supra note 8 and accompanying text.

76. A prime example of the Supreme Court's willingness to accept Chicago School economics is Continental T.V., Inc. v. GTE Sylvania Inc., 433 U.S. 36, 54-56 (1977), in which the Court, citing both Richard Posner and Robert Bork, overruled a per se rule against non-price vertical restraints. See also Lawrence T. Festa, III, Comment, Eastman Kodak Co. v. Image Technical Services, Inc.: The Decline and Fall of the Chicago Empire?, 68 NOTRE DAME L. REV. 619, 621-22 (1993) (discussing the Supreine Court's decision in Sylvania). In Sylvania, "the Court based its decision on the theory that nonprice vertical restraints are necessary to prevent free-riding on [the defendant's] pre-sale services, without denanding evidence of the provision of these services or the incidence of free-riding in the absence of the restraints." Joseph Kattan, Economic Theory as a Substitute for Evidence in Antitrust: The Difficulty of Erecting Rules of Law on Theory Afier Kodak, 23 ANTITRUST LAW \& ECON. REV. 13, 24 (1991). 
behind the enactment of the earlier antitrust legislation: decentralizing concentrated market power and providing the consumer with competitive price, output, quality, and diversity of goods available in the market. ${ }^{77}$ These ideals should not be ignored in interpreting and applying the antitrust laws.

The Supreme Court recently has indicated that it has not fully einbraced a strict, Chicago-school theory of antitrust. ${ }^{78}$ Moreover, the Court recently has lent support to the use of an approach that focuses on economic realities and factual predicates. ${ }^{79}$ Future courts addressing exclusive dealing arrangements therefore should permit firms to proffer efficiency justifications in defense of exclusivity, but should not assume the existence of procompetitive effects im the absence of demonstrable market efficiencies. When proffered busimess justifications are weak, or when firms fail to present evidence that their exclusive contracts are used solely to reduce costs or prevent free-riding, courts should not dismiss claims alleging antitrust violations. Analysis of actual coinpetitive effects, not smiply mechanical application of theoretical economic models, is required in order to construct a framework for exclusive dealing that serves the purposes of the antitrust laws. The ticketing service mdustry provides a factual setting that is conducive to such construction.

\section{Historical Judicial TREATMENT OF EXClusive DeAling AND RECENT ENFORCEMENT TRENDS}

The starting point for analysis of exclusive dealing cases is the Supreme Court's decision in Standard Stations, in which the Court utilized a "quantitative substantiality" test to evaluate the legality of exclusivity agreenents. ${ }^{80}$ This test focuses singularly on the

77. See supra text accompanying notes 1-4.

78. See Festa, supra note 76 , at 620 .

79. See Eastman Kodak Co. v. Image Technical Serv., 504 U.S. 451, 466-67 (1992) (citing cases); see also infra Section III.

80. 337 U.S. at 299 (1948). This case was decided under § 3 of the Clayton Act. 38 Stat. 730 \& 3 (1913), which provides:

[I]t shall be unlawful for any person engaged in commerce, in the conrse of such commerce, to lease or make a sale or contract for sale of goods, wares, merchandise, machinery, supplies or other commodities ... . where the effect of such lease, sale, or contract for sale of such condition, agreement or understanding may be to snbstantially lessen competition or tend to create a monopoly in any line of commerce. 
degree of foreclosure in the relevant line of commerce as the basis for an antitrust violation. The Court concluded that on the facts before it, ${ }^{81}$ the statutory requirement of proof-that the likely effect of defendant's exclusive agreements was to "substantially lessen competition"-could be met by proof that a substantial portion of commerce was in fact affected. ${ }^{82}$ The Court did not require any factual demonstration of additional factors likely to impact competition negatively, such as the number and strength of other competitors in the industry, or the presence of barriers to entry. ${ }^{83}$ Under this analysis, the assessment of actual or probable competitive effects beyond a numerical measure of market share is irrelevant.

The Supreme Court properly retreated from this position in subsequent decisions. More recent cases lave looked beyond simple market foreclosure to examine the actual or probable anticompetitive effects of exclusive dealing arrangements. Tampa Electric Co. v. Nashville Coal Co. ${ }^{84}$ altered the analysis of exclusive dealing arrangements by focusing on qualitative factors in evaluating possible antitrust violations, developing a three-pronged mquiry for evaluating exclusivity arrangements. First, courts must determine the relevant line of commerce (i.e., the types of products or services involved) "on the basis of the facts peculiar to the case." ${ }^{15}$ Second, courts must carefully define the relevant geographic market and evaluate the degree of foreclosure in terms of this market. ${ }^{86}$ Finally, courts must determine whether the exclu-

The analysis under this section is almost identical to $\S 1$ of the Sherman Act. See BoRK, supra note 7, at 299 ("The law deals with [exclusive dealing] contracts under Section 3 of the Clayton Act ... and Section I of the Sherman Act, which ... has come to apply doctrine distinguishable from the doctrine of Clayton 3 only by a metaphysician."). Ticketnaster's practices, however, are unassailable under the Clayton Act because they involve a service, not a "commodity." See Kennedy Theater Ticket Serv. v. Ticketron, 342 F. Supp. 922, 927 (E.D. Pa. 1972) ("[S]ince the intangible aspects of the admission tickets are dominant over the tangible aspects thereof, an admission ticket does not constitute a 'commodity' within the meaning of the [Clayton] Act.").

81. The defendant in Standard Stations owned gasoline refineries and sold petroleum products under exclusive supply contracts with independent service stations constituting $1.6 \%$ of the retail gasoline outlets in the area. Total sales under exclusive agreements amounted to $6.7 \%$ of the total gallonage sold in the entire market that year. Standard Stations, 337 U.S. at 295.

82. Id. at $299,314$.

83. Id. Barriers to entry will be discussed infra text accompanying notes 159-71.

84. 365 U.S. 320 (1961).

85. Id. at 327 .

86. Id. 
sive dealing contracts constitute a "substantial share" of the relevant market. ${ }^{87}$

In evaluating the "substantiality" of the market foreclosure in any given case, the Court reasoned that

it is necessary to weigh the probable effect of the contract on the relevant area of effective competition, taking into account the relative strength of the parties, the proportionate volume of commerce involved ... and the probable immediate and future effects which pre-emption of that share of the market might have on effective competition therein. ${ }^{88}$

This analysis represents a less rigid approach than the standard articulated in Standard Stations. In Tampa Electric, the Court focused on the actual impact of the exclusive agreements on competition in the coal inarket; a significant percentage of foreclosure was not sufficient to subject a firm to antitrust hability. ${ }^{89}$

The standard that has emerged, then, requires proof of substantial market foreclosure in addition to a demonstration of possible immediate and future effects on competition. ${ }^{90}$ Tampa Electric further suggests that this analysis should be balanced against any possible efficiencies or competitive benefits that result from the exclusivity. ${ }^{91}$ This approach reflects an emphasis on the balancing of qualitative factors; such a balancing approach has been labelled the "rule of reason" standard and has been crucial in subsequent analyses of exclusive dealing arrangements. ${ }^{92}$

87. Id. at 328. The requirement of careful market definition was extremely important in Tampa Electric. The Court defined the market very broadly, and as a result, ruled in favor of the defendant on the basis that its share of the total coal market was less than $1 \%$ and that preemption of competition in fact did not tend to foreclose competition in that market. Id. at 333 .

88. Id. at 329.

89. Id. at 327-29 (analyzing the effects of the disputed contract on competition, imcluding numerous factors other than the percentage of foreclosure).

90. See id; U.S. Healthcare, Inc. v. Healthsource, Inc., 986 F.2d 589, 597 (1st Cir. 1993).

91. See Tampa Electric, 365 U.S. at 334.

92. The rule of reason standard is perhaps most clearly stated in Chicago Board of Trade v. United States, 246 U.S. 231 (1918).

The true test of legality [under Section 1 of the Sherman Act] is whether the restraint imposed is such as merely regulates and perhaps thereby promotes competition or whether it is such as may suppress or even destroy competition. To determine that question the court must ordinarily consider the facts peculiar to the business to which the restraint is apphed; its condition before and after the restraint was imposed; the nature of the restraint and its effect, actual or probable. 
The Supreme Court has not spoken directly on the legahty of exclusive dealing arrangements in over thirty years. The only guidance that the Court has provided since Tampa Electric is through Justice O'Connor's concurring opinion in Jefferson Parish Hospital District No. 2 v. Hyde. ${ }^{93}$ In that case, the majority assessed the legality of an exclusive contract between a hospital and a firm of anesthesiologists under a tying theory. ${ }^{94}$ The concurrence, however, argued that the arrangement should have been analyzed as an exclusive dealing claim..$^{95}$ O'Connor's opinion applies Tampa Electric's rule of reason approach to exclusive dealing and provides some support for the view that actual economic effects must be taken into account in analyzing exclusive dealing contracts. ${ }^{96}$

\section{Id. at 238 .}

The alternative to this approach is a per se rule of illegality, which courts have consistently refused to apply to exclusive dealing and most other forms of vertical restraints. "Per se rules of illegality are appropriate only when they relate to conduct that is manifestly anticompetitive." Continental T.V., Inc. v. GTE Sylvania, Inc., 433 U.S. 36, $49-50$ (1977). A per se rule, however, is essentially a predetermined application of the rule of reason to a category of conduct that tends to suppress or destroy competition. See Marc A. Fajer, Taming the Wayward Children of Monsanto and Sylvania: Some Thoughts on Developmental Disorders in Vertical Restraints Doctrine, 68 TEMPLE L. REV. 1, 9 (1995) ("The rule of reason and per se analysis are but two methods of determining whether a restraint is 'unreasonable,' i.e., whether its anticompetitive effects outweigh its procompetitive effects.") (citing Atlantic Richfield Co. v. USA Petroleum Co., $110 \mathrm{~S}$. Ct. 1884, 1893 (1990)).

93. 466 U.S. 2 (1984).

94. Tying occurs when a seller of product $\mathrm{A}$ conditions the purchase of $\mathrm{A}$, the tying product, on the purchase of product B, the tied product. See BoRK, supra note 7, at 365 . At issue in Jefferson Parish was the vahidity of an exclusive contract between the defendant hospital and a firm of anesthesiologists. The Fifth Circuit had ruled that the case involved a tying arrangement because the "users of the hospital's operating rooms (the tying product) are also compelled to purchase the hospital's chosen anesthesia service (the tied product)." Jefferson Parish, 466 U.S. at 8.

Tying arrangements are similar in nature to exclusive dealing arrangennents in that both impose vertical restraints on competition. However, courts have treated the two practices differently, generally according much harsher treatinent to tying practices.

95. Justice O'Connor was joined by Chief Justice Burger, Justice Powell, and Justice Rehnquist. This split as to the proper characterization of the case suggests that the decision nay have an important impact on both tying and exclusive dealing law. See Richard M. Steuer, Exclusive Dealing After Jefferson Parish, 54 ANTrTRUST L.J. 1229, 1229 (1985).

96. O'Connor reasoned that

[e]xclusive dealing is an unreasonable restraint on trade only when a significant fraction of buyers or sellers are frozen out of a market by the exclusive deal. When the sellers of services are numerous and mobile, and the number of buyers is large, exclusive-dealing arrangements of narrow scope pose no threat of adverse economic consequenccs.

Jefferson Parish, 466 U.S. at 45 (citations ormitted). Consequently, O'Connor found that a $30 \%$ foreclosure in the situation before the Court did not foreclose a significant fraction 
Lower courts generally have followed Tampa Electric's approach, typically requiring proof of a significant negative impact on competition in the relevant market in order to estabhish the illegality of an exclusivity agreement. ${ }^{97}$ Once substantial foreclosure $\mathrm{m}$ the relevant market is found, courts will examine the additional factors articulated in the Tampa Electric opinion in evaluating possible anticompetitive effects. Courts tend to look at numerous market conditions im applying the rule of reason analysis, but focus primarily on three factors emphasized in Tampa Electric: (1) the percentage of the market foreclosed; (2) the ease of entry into the defined market; and (3) the duration and terminability of the exclusive contracts. ${ }^{98}$ In order to discover and punish anticompetitive conduct, courts should examine each of these factors carefully in exclusive dealing cases.

The Supreme Court's decision in Eastman Kodak Co. v. Image Technical Services, Inc. ${ }^{99}$ marks a significant recent development in the course of judicial treatinent of vertical restraints. Although Eastman Kodak is a tying case, it has broad imphications for antitrust law and lends support to a judicial approach that

of the relevant market and therefore did not constitute an unreasonable restraint of trade. $I d$. at 47.

The majority also emphasized the importance of actual economic effects in declining to apply a per se rule to the arrangement. $I d$. at 29 (requiring the plaintiff to prove that the contract unreasonably restrained competition, a burden that "necessarily involves an imquiry into the actual effect of the exclusive contract on competition among anesthesiologists").

97. See, e.g., Ryko Mfg. Co. v. Eden Serv., 823 F.2d 1215, 1233-34 (8th Cir. 1987), cert. denied, 484 U.S. 1026 (1988). See also Roland Machinery Co. v. Dresser Indus., Inc., 749 F.2d 380 (7th Cir. 1984). The Seventh Circuit noted:

Although the Supreme Court has not decided an exclusive-dealing case in many years, it now appears most unlikely that such agreements ... will be judged by the simple and strict test of Standard Stations. They will be judged under the Rule of Reason, and thus condemned ouly if found to restrain trade unreasonably.

Id. at 393. Cf. Strasser, supra note 12, at 970 :

[T] he rule of reason has been given little analytical content because traditional antitrust policy has reflected only an incomplete understanding of the workings of vertical markets and vertical distribution systems as economic and commercial phenomena. Consequently, these exclusivity agreements are uniformly permitted with little or no analysis.

98. See, e.g., Virgin Atlantic Airways v. British Airways PLC, 872 F. Supp. 52, 66 (S.D.N.Y. 1994); Barr Laboratories, Inc. v. Abbot Laboratories, 1989-1 Trade Cas. (CCH) I 68,647, at 61,404 (D.N.J. 1989); Kellam Energy, Inc. v. Duncan, 668 F. Supp. 861, 884 (D. Del. 1987).

99. 504 U.S. 451 (1992). 
analyzes actual competitive effects closely. Some commentators have interpreted this decision as signalling the Supreme Court's move away from analysis based on Chicago School economic theory and toward a more fact-intensive approach that results in closer scrutimy of vertical restraints. ${ }^{100}$

In Eastman Kodak, the plaintiffs were imdependent service organizations (ISOs) claiming that the defendant's policy of limiting the availability of replacement parts for its equipment harmed them competitively. The plaintiffs argued that Kodak illegally tied the sale of service for Kodak machines to the sale of parts; ${ }^{101}$ this policy allegedly made it difficult for the ISOs to compete with Kodak in servicing Kodak equipment. Kodak's primary defense was that it did not possess market power in the relevant market-here, the parts and service aftermarket. ${ }^{102}$

Kodak urged the Court to adopt a substantive legal rule that "equipment competition precludes any finding of monopoly power in derivative aftermarkets." 103 Dismissing Kodak's argument that an examination of the facts was unnecessary when the issue was market power in an aftermarket, the Court stated:

Legal presumptions that rest on formalistic distinctions rather than actual market realities are generally disfavored in antitrust law. This Court has preferred to resolve antitrust claims on a case-by-case basis, focusing on the "particular facts disclosed by the record." ... In determining the existence of market power ... this Court has examined closely the economic reality of the market at issue. ${ }^{104}$

The Court, then, required a detailed factual inquiry and ultimately demied the defendant summary judgment. ${ }^{105}$

The Eastman Kodak decision indicates that economic theory alone cannot provide the basis for a successful antitrust defense. ${ }^{106}$ The Court engaged in a thorough analysis of Kodak's

100. See, e.g., Festa, supra note 76, at 619; Kattan, supra note 76, at 13.

101. Eastman Kodak, 504 U.S. at 459.

102. Specifically, Kodak argued that because competition existed in the equipment market, the possibility that it exercised market power in the service and parts markets (the aftermarkets) "'simply makes no economic sense." Id. at 467 (quoting Matsushita Elec. Indus. Co. v. Zenith Radio Corp., 475 U.S. 574, 587 (1986)).

103. Id. at 466 (quoting Brief for Petitioner at 33).

104. Id. at 466-67 (quoting Maple Flooring Mfrs. Ass'n v. United States, 268 U.S. 563, 579 (1925)).

105. Id. at 469,477 .

106. "In the least, it suggests that resort to pure economic theory in lieu of direct 
economic theory and of actual market effects. For example, Kodak argued that higher service prices would lead to a "disastrous" drop in equipinent sales; at the same time, low service prices would lead to an increase in equipment sales. The Court took Kodak's argument one step further and noted that according to this theory, Kodak would be expected to take advantage of lower-priced ISO service to expand equipment sales. ${ }^{107}$ However, the Court found that Kodak had instead adopted a restrictive sales policy designed to eliminate lower-priced ISO service, an act expected to devastate Kodak's equipment sales. ${ }^{108}$ As expected, service prices for Kodak customers increased, but no evidence existed of a corresponding decrease in sales of Kodak equipment. ${ }^{109}$ The Court thus tested Kodak's proffered economic theory against actual market responses; Kodak's theory could not survive such close scrutiny. This decision suggests that future courts addressing vertical restraints should be reluctant to grant summary judgment to defendants who claim their practices generally produce procompetitive results without specific proof that actual procompetitive effects outweigh any harm to competition.

In addition to judicial review of alleged antitrust violations, enforcement by the United States Department of Justice is important in preventing and redressing anticompetitive conduct. Several recent developments in the policy of the Antitrust Division of the Justice Department indicate the direction in which antitrust enforcement is moving and suggest more meaumgful ways to address exclusive dealing. The current Assistant Attorney General for the Antitrust Division, Anne Bingaman, recently has stated that the Justice Department will subject exclusive dealing and other nonprice vertical restraints to a "meaningful Rule of Reason analysis."110 Bingaman has spoken directly on the Supreme Court's decision in Eastman Kodak, interpreting the inajority opinion in that case as requiring more vigorous analysis into the facts of an individual case before disposing of the claim on summary judginent. ${ }^{111}$ Moreover, the Justice Department's current policy is to

evidence may be a risky course for antitrust defendants." Kattan, supra note 76, at 20.

107. Eastman Kodak, 504 U.S. at 476.

108. Id.

109. Id.

110. Remarks of Assistant Attorney General Anne K. Bingaman to the ABA Antitrust Section, New York, NY, in 7 Trade Reg. Rep. (CCH) II 50,110, at 48,924 (Aug. 10, 1993) (emphasis added).

111. Nomination Hearing of Anne Bingaman to Be Asst. Attorney Gen, Antitrust Div., 
enforce the law vigorously, with fact-intensive inquiries into actual competitive effects. ${ }^{112}$ This approach does not ignore economic theory; instead, it employs a balanced approach, "one that applies sound theoretical analysis together with an appreciation that the facts on occasion will not square with theory."113

The policies of the Justice Department inevitably reflect changing political currents. ${ }^{114}$ In hight of recent political upheavals in Congress, the present policy of strict antitrust enforcement may be altered by the end of 1996. However, the Justice Department's intention to scrutinize the conditions surrounding exclusive dealing arrangements more closely than it has in recent years, utilizing both a doctrinal and a factual analysis, ${ }^{115}$ represents the proper approach to judicial analysis of exclusive dealing. Although courts are not bound by the Department's enforcement policy, the Eastman Kodak decision suggests that courts too should begin to analyze exclusive dealing carefully.

\section{Exclusive Dealing IN THE COMPUTERIZed Ticket DISTRIBUTION INDUSTRY}

Courts must carefully examine the numerous factors articulated in the Supreme Court's decisions and in subsequent lower court cases when evaluating the legality of exclusive dealing arrangements. In analyzing these factors, they should conduct rigorous factual imquiries imto market conditions and responses, and they should refuse to proceed on assumptions based purely on economic theory. In order to undertake the proper balancing required by the rule of reason, courts inust vigilantly require factual predicates before imposing or dismissing antitrust liabihty.

Before the Senate Comm. on the Judiciary, 103d Cong., 1st Sess. 16-17 (1993) (statement of Anne K. Bingaman). Bingaman further emphasized that "every case is unique, every market is unique . . . the set of companies and facts are the lifeblood of antitrust." Id.

112. Remarks of Asst. Attorney Gen. Anne K. Bingaman to the ABA Antitrust Section, New York, NY, in 7 Trade Reg. Rep. (CCH) II 50,110 (Aug. 10, 1993).

113. Id.

114. See, e.g., Fajer, supra note 92 , at 8 (noting that the Justice Department brought no legal challeuges to vertical restraints during the Reagan and Bush administratious, reflecting a skepticism that such restraints ever could result in coinpetitive harm.); Festa, supra, note 76, at 622 (describing President Ronald Reagan's election and his subsequent appointments to the Antitrust Division of the Department of Justice and to the judiciary as events that inagnified the Chicago School's effect on antitrust jurisprudeuce).

115. See Text of Bingaman's Address to ABA's Antitrust Section, in 65 Antitrust \& Trade Reg. Rep. (BNA) 250 (Aug. 12, 1993). 


\section{A. Market Definition}

Careful definition of the relevant market is crucial to the application of the rule of reason in exclusive dealing arrangements. Indeed, the assessment of the relevant market frequently determines the outcome of a case. ${ }^{116}$ The Supreme Court has identified accurate market definition as the "prime factor" in determining whether an exclusivity agreement effectively forecloses competition in the relevant "line of commerce."117 Market definition, however, is not undertaken as an end im itself. It serves only as an analytical framework for identifymg the unlawful exercise of market power. ${ }^{118}$

The relevant market is "the area of effective competition" within which the defendant conducts business. ${ }^{119}$ Market definition generally consists of two components: the product market, which describes the product or service involved, and the geographic market, which describes the geographic area in which the defendant operates. ${ }^{120}$ With respect to each component, the less expansive the market definition, the nore likely a plaintiff will prevail on an antitrust claim. ${ }^{121}$

One niethod of defining the relevant product market is in terms of possible substitutes for the antitrust defendant's product or service. ${ }^{122}$ In these terms, the market consists of the product or service of the firm as well as those products or services viewed as close substitutes by buyers. ${ }^{123}$ The Justice Departinent ineasures the appropriate market by determining what effects would result if a hypothetical monopolist of a given product or service iniposed a "sinall but significant and nontransitory" imcrease im

116. James A. Keyte, Market Definition and Differentiated Products: The Need for a Workable Standard, 63 ANTTRRUST L.J. 697, 697 (1995).

117. See Tampa Electric Co. v. Nashville Coal Co., 365 U.S. 320, 329 (1961).

118. See Keyte, supra note 116 at 697.

119. Tampa Electric, 365 U.S. at 328.

120. See Brown Shoe Co. v. United States, 370 U.S. 294, 324 (1962).

121. The Justice Department has examined the relevant market in terms of groups of products and services in which a firm employing a particular restraint could exercise market power effectively. See U.S. Dep't of Justice and FTC Horizontal Merger Guidelines, 57 Fed. Reg. 41,552 [heremafter Horizontal Merger Gnidelines]. When the identified market is limited in expanse, a demonstration of a high concentration of market power is easier to make.

122. See, e.g., United States v. E.I. Du Pont de Nemours \& Co., 351 U.S. 377, 379-81 (1957); Brown Shoe Co., 370 U.S. at 297.

123. See E.I. Du Pont, 351 U.S. at 393. 
price. ${ }^{124}$ When the price increase would not be profitable because buyers would shift to other products, they add the product or service that is the "next best substitute," taking into account the effects of the exclusive dealing arrangement. They then make the same inquiry agam until one group of products is identified for which a monopolist's price increase would be profitable. ${ }^{125}$

The ticket distribution mdustry presents several alternative market definitions. Antitrust defendants generally attempt to define the market broadly, diminishing the appearance of sizeable foreclosure or market power. One plausible product narket definition in the ticketing context would incorporate the retail sale of all entertainment tickets in a given geographic area. This would $\mathrm{m}$ clude numerous sinall, regional venues that do not deal in the large-scale distribution of tickets, but rather sell tickets to entertainment events only through their own box offices. ${ }^{126}$ Under this definition, the possibility that a single firm's exclusive contracts might effectively foreclose a substantial sliare of the retail sale of all entertainment events is not very great. ${ }^{127}$

However, the purpose of defining the relevant market is an important consideration. When choosing between alternative market definitions, courts should ask, "What is the antitrust question in this case that market definition aims to answer?" 128 In the present context, naarket definition is intended to determine whether competition has been foreclosed unreasonably such that other firms within the same narket do not have the ability to keep the dominant firm from raising prices to supracompetitive levels. ${ }^{129}$ With this purpose in inind, the relevant market is defined more plausibly as off-site ticket sales in major metropolitan areas.

124. Horizontal Merger Guidelines, 57 Fed. Reg. at 41,554 .

125. Id. at 41,555 .

126. See Stern, supra note 20 , at $374-75$.

127. In fact, Fred Rosen, the president of Ticketmaster, testified before Congress that Ticketmaster accounted for only $2 \%$ of the 1.5 billion tickets sold to entertainment events nationwide. See Ramirez, supra note 25, at C1. The New York Times reports, however, that two-thirds of this figure consists of tickets for museums, amusement parks, county fairs, and other events. In contrast, Ticketmaster, according to the Times, holds $37 \%$ of the market for tickets to major concerts and sporting events. Id. In a regional market, this percentage could be significantly higher. See infra note 141 and accompanying text.

128. U.S. Healthcare, Inc. v. Healthsource, Inc., 986 F.2d 589, 598 (1993).

129. See United States v. Grinnell Corp., 384 U.S. 563, 571 (1966) (noting that the relevant narket should include the products or services to which "customers may turn ... if there is a slight increase in the price of the main product [or service]"). 
Ticket distribution companies such as Ticketmaster are im direct competition not with the venue's box office ticket sales, ${ }^{130}$ but with other distribution companies of its kind. The threatened danger to competition is not that a venue, which has already contracted with a ticket distribution company to sell its tickets, will face decreased sales at its own box office; rather, the danger is that another ticketing service company is demed the opportumity to compete for its own contract to sell tickets for that venue.

Moreover, Ticketmaster, in many situations, not only enjoys the exclusive right to sell tickets at retail outlets and over the phone, but also limits the number of hours that the venue box office remaims open and the number of tickets that the box office may sell. ${ }^{131}$ Finally, a very large percentage of tickets for major concerts are sold at outlets or over the telephone; tickets for especially popular entertainment events sometimes sell out im only minutes, with Ticketmaster selling essentially every available ticket. Because a venue's sale of tickets at the box office does not compete directly with Ticketmaster and cannot preclude Ticketmaster froin exercising market power and raising its prices on the sale of tickets, box office sales should not be considered part of the relevant market.

Including ticket sales to all entertainment events, no matter how large or small, in the relevant market, would similarly distort the requisite examination of Ticketmaster's exercise of market power. Off-site ticket sales to large entertainment events concededly constitute ouly a narrow segment of ticket sales to all entertainment events, and excludes countless small, imdependent entertainment venues that distribute tickets only through their own box offices. ${ }^{132}$ However, the purpose of Ticketmaster's exclusivity contracts with venues and promoters is to exercise control over the computerized distribution of tickets, not the retail sale of all entertainment tickets. ${ }^{133}$ Within the computerized ticket service market, exclusive dealing arrangements provide Ticketmaster with the means to exercise power over price, and consequently, to increase service charges substantially.

130. See Stern, supra note 20 , at 375.

131. Id. at 354 .

132. Id. at 374-75.

133. Id. at 375 . 
An analogous situation arose in Twin City Sportservice $v$. Charles O. Finley \& Co., ${ }^{134}$ a case in which an owner of a baseball club alleged antitrust violations against a concessionaire who held an exclusive concession franchise contract for events at the baseball stadium. Supporting the trial court's narrowing of the relevant market definition, the Ninth Circuit reasoned:

The district court found that effective competition existed only for concession franchises that a national concessionaire would find profitable by reason of dollar volumes. The record amply supports the district court's finding that effective competition did not encompass every concession franchise within the relevant line of commerce. 135

The Ninth Circuit's opinion supports the argument that neither small, independent venue box offices nor small-scale ticket distributors for minor entertainment events are relevant to a determination of the competitive atmosphere of the computerized ticketing service industry. Therefore, in order to assess the ability of other ticketing service companies to compete with Ticketmaster, the product market should be defined restrictively.

The next step in product market definition is an interchangeability mquiry, or an inquiry into whether or not any acceptable substitute for the product or service exists. ${ }^{136}$ Utilizing the Justice Department's test, ${ }^{137}$ if Ticketmaster imposed a small but significant increase im its service charges, those products to which consumers would then shift should be imcluded in the relevant market. The structure of the ticket distribution industry, however, does not provide any alternative to consumers who are unhappy with price mcreases. Venne box offices are the only possible option, but they fail to provide an adequate alternative for several reasons. First,

134. 676 F.2d 1291 (9th Cir.), cert. denied, 459 U.S. 1009 (1982).

135. Id. at 1300 (emphasis added).

136. The most relevant factor im this determination is the cross-elasticity of demand faced by the defendant, or the degree to which the defendant's sales fall as its price rises and consumers choose competitors' products as substitutes. When cross-elasticity of two products is high, (i.e., when consumers change their consumption of one product in response to a change in the price of another at a high rate), the two products should be included in the same market. Although the Snpreme Court has ruled that "reasonable interchangeability" and cross-elasticity of demand determine the "outer boundaries" of the product market, it has provided httle guidance on the degree of cross-elasticity required. See Brown Shoe Co. v. United States, 370 U.S. 294, 325 (1962); Keyte, supra note 116, at 699.

137. See supra note 124 and accompanying text. 
venue box office sales lack the convenience of computer ticketing sales, which often take place over the telephone or in a ticket outlet that may be easily accessible to the consumer. Second, even if a ticketing company has not reserved the right to distribute tickets from the box office, it frequently sells all available tickets for popular events over the telephone. ${ }^{138}$ Because Ticketmaster controls exclusive contracts with a majority of venues and promoters nationwide, consumers are forced to either buy tickets through Ticketmaster or not attend these events. As one commentator reasoned, "If venue box offices are part of the relevant product market, one would expect to see consumers increasingly purchasing their tickets at the box office with every increase in ... service charges. However, this is clearly not the case."139 The relevant inarket, therefore, should be defined to include only off-site ticket sales.

The definition of the relevant geographic narket is similar to the definition of the product market. ${ }^{140}$ The Supreme Court has pointed out that "Congress prescribed a pragmatic, factual approach to the definition of the relevant market and not a formal, legalistic one. The geographic market selected must, therefore, both 'correspond to the commercial realities' of the industry and be economically significant."141 This rationale suggests that the unique structure of the ticketing service industry must be considered carefully in determining the appropriate geographical narket definition.

The relevant geographic market is the "area in which the seller operates, and to which the purchaser can practicably turn for supplies [or services]."142 Venues and promoters operate on a local level; when they compete among themselves for the opportumty to host entertainment events, they do so only on a regional basis, suggesting that the effective area of competition for ticketing services is local. For example, a large venue in New York City does not affect the operations of a comparably sized venue in Los Angeles. Ticketmaster's contract with the Los Angeles venue simi-

138. See supra text accompanying notes 131-32.

139. See Stern, supra note 20, at 376 n.194.

140. Brown Shoe Co., 370 U.S. at 336 ("The criteria to be used in determining the appropriate geographic market are essentially similar to those used to determine the relevant product market.").

141. Id. at $336-37$.

142. Tampa Elec. Co. v. Nashville Coal Co., 365 U.S. 320, 327 (1961). 
larly has no effect on its contract with the New York, venue. Therefore, although Ticketmaster is a national enterprise, the geographic market in which venues and promoters contract for Ticketmaster's services is local. ${ }^{143}$ Indeed, the very existence of regional ticket distributors that are unable to compete with Ticketmaster on a national basis but that may succeed in contracting with smaller venues at a local level suggests that the relevant market is local.

\section{B. Foreclosure}

Once a court has identified the relevant market, it must then calculate the degree of foreclosure within that market in order to evaluate the legality of any exclusive dealing arrangement. ${ }^{144}$ The presence or absence of proof that the relevant market is in fact being foreclosed may indeed determine the outcome of a case. ${ }^{145}$ However, analyzing the degree of foreclosure in a particular market is not a straightforward task. Courts must first determine the degree of foreclosure that is sufficient to constitute an antitrust violation.

While courts lave not applied strict threshold percentage requireinents for a finding of illegahity, some trends have emerged. Generally, when less than $10 \%$ of the relevant market has been foreclosed, no violation is found. ${ }^{146}$ The rationale for this result

143. Given the purpose of market definition-determining the existence of market power-the selection of a local market makes sense. This is illustrated by one commentator's analysis of Ticketmaster's control over the Northern and Southern California markets. Stern, supra note 20, at 355-56. In Northern California, BASS, a regional ticketing company, entered into a licensing agreement that allowed BASS to use Ticketınaster's computer systems and its name in advertising. At the same time, BASS agreed not to compete with Ticketmaster in the Southern California market. Id. at 355 . BASS liad a $75 \%$ share of the off-site ticketing market in Northern California, and Ticketınaster maintained a 95\% share of San Diego's off-site ticketing market. Id. at 376-77. These facts indicate that a local market definition demonstrates when a company has accumulated sufficient market power to exercise control over price, and therefore constitutes the proper geographic market.

144. See U.S. Healthcare, Inc. v. Healthsource, Inc., 986 F.2d 589, 596 (1st Cir. 1993) ("In any event, under Tampa [Electric] the ultimate issue in exclusivity cases remains the issue of foreclosure and its consequences.").

145. See Richard M. Steuer, Vertical Restraints in the Nineties, 62 ANTITRUST L.J. 717, 724 (1994).

146. See, e.g., In re Beltone Electronics Corp., 100 F.T.C. 68, 184 (1982) (holding $7-8 \%$ foreclosure not sufficient to find violation); Ryko Mfg. Co. v. Eden Servs., 823 F.2d 1215, 1234 (8th Cir. 1987) (8-10\% not sufficient), cert. denied, 484 U.S. 1026 (1988); see also Department of Justice Vertical Restraints Guidelines, 50 Fed. Reg. 6,263, 6,269 
is that such an msignificant amount is not likely to have any anticompetitive effects. Conversely, when an obviously large portion of the market is foreclosed by exclusivity agreements, courts have found that anticompetitive effects are likely. Specifically, the cases indicate that foreclosure may be sufficient when it is greater than $50 \% .^{147}$

More problematic is a foreclosure percentage that falls between these percentages. Historically, courts addressing market foreclosure between $10 \%$ and $50 \%$ have ruled inconsistently. ${ }^{148}$ However, the Jefferson Parish decision, in which Justice O'Connor's concurring opinion found a $30 \%$ foreclosure insufficient, may be an imdication that courts will begin to apply a higher threshold requirement. ${ }^{149}$ Subsequent cases have, in fact, found percentages up to $40 \%$ lawful. ${ }^{150}$ Even with these general thresholds in mind, however, courts must inake any determination of market foreclosure by looking to actual competitive effects. ${ }^{151}$

The First Circuit has interpreted Tampa Electric to mean that not only foreclosure but also its consequences are the "ultimate issue" in exclusive dealing cases. ${ }^{152}$ The percentage of the market tied up with exclusive dealing contracts, then, does not in itself indicate whether or not the foreclosure is illegal. In measuring foreclosure, both the percentage of the inarket tied up and the

(1985) [hereinafter Vertical Restraints Guidelines] (safe harbor for $10 \%$ or less).

147. See, e.g., United States v. Dairymen, Inc., 758 F.2d 654 (6th Cir.) (finding 50\% foreclosure sufficient to impose hability), cert. denied, 474 U.S. 822 (1985); Oltz v. St. Peter's Community Hosp., 656 F. Supp. 760, 763 (D. Mont. 1987) (84\% sufficient), affd, 861 F.2d 1440 (9th Cir. 1988); Kohler Co. v. Briggs \& Stratton Corp., 1986-1 Trade Cas. (CCH) I67,047, at 62,416 (E.D. Wis. 1986) (62\% sufficient).

148. See, e.g., Twin City Sportservice v. Charles O. Finley \& Co., 676 F.2d 1291, 1298 (9th Cir.) (long-term foreclosure of $24 \%$ of market unlawful), cert. denied, 459 U.S. 1009 (1982); Anerican Motor Inns v. Holiday Inns, 521 F.2d 1230, 1252 (3rd Cir. 1975) (15\% insufficient to establish hability); Servicetrends v. Siemens Medical Sys., 870 F. Supp. 1042, 1065 (N.D. Ga. 1994) (32-38\% market foreclosure not per se legal).

149. Jefferson Parish Hosp. Dist. No. 2 v. Hyde, 466 U.S. 2, $46-47$ (1984).

150. See, e.g., Sewell Plastics, Inc. v. Coca-Cola Co., 720 F. Supp. 1196, 1212-14 (W.D.N.C. 1989) (40\% insufficient to impose liability), affd in part, 912 F.2d 463 (4th Cir. 1990); Gonzalez v. Insignares, 1985-2 Trade Cas. (CCH) Il 66,701, at 63,335 (N.D. Ga. 1985$)$ (40\% insufficient). But see Servicetrends, 870 F. Supp. at 1065 (32-38\% not per se legal).

151. See In re Beltone Electronics, Corp., 100 F.T.C. 68, 217-18 (1982). The Commission, while finding in favor of the defendant, nevertheless refused to find clearly lawful the foreclosure of $16 \%$ of market sales, or $7-8 \%$ of dealers. The Commission emphasized qualitative standards and looked for an adverse effect on interbrand competition.

152. See U.S. Healthcare, Inc. v. Healthsource, Inc., 986 F.2d 589, 596 (1st Cir. 1993). 
practical effect of binding that percentage of the inarket to exclusive contracts are essential factors. ${ }^{153}$ For example, foreclosure is more dainaging to coinpetition when the defendant has a large market share, ${ }^{154}$ when the industry is concentrated, ${ }^{155}$ and when no alternative means of distribution are available. ${ }^{156}$

Analysis of market foreclosure in the coinputerized ticket distribution industry is complicated by the infrastructure of the industry. "When an exclusive dealing arrangement involves an enduser, the foreclosure effect is straightforward; sales to the end-user are foreclosed.... When distributors are involved, however, this kind of one-to-one analysis is not reliable."157 Therefore, the nost accurate determination of foreclosure will result from an examination of the extent to which coinpeting ticketing service companies are foreclosed from reaching the ultimate market-the consumers of the product. ${ }^{158}$ Any meaningful analysis thus must contemplate the obstacles that Ticketmaster has created in keeping actual and potential competitors from reaching the ultimate consumer.

The extent to which Ticketmaster's exclusive dealing contracts have tied up the market is the subject of ongoing dispute. The New York Times has reported that Ticketmaster has exclusive rights to alinost two-thirds of the nation's ten million seats at major halls. ${ }^{159}$ Another report states that Ticketınaster has exclusive contracts with sites holding $45 \%$ of the nation's seats. ${ }^{160} \mathrm{Ei}$ ther of these amounts is likely to have an adverse effect on competition and fall within the general parameters discussed above for determining whether the quantitative standard is sufficient; and judging from the absence of significant competitors in the relevant market, these amounts already appear to have affected competition adversely.

By removing venues and promoters froin the reach of new ticket distribution coinpames, the exclusive dealing contracts seemingly impair the ability of actual or potential competitors of

153. See id.

154. See Strasser, supra note 12, at 985 .

155. Id. at $985-86$.

156. See Steuer, supra note 145 , at $937-38$.

157. See id. at 931.

158. See id.

159. See Ramirez, supra note 25.

160. Id. 
Ticketmaster to operate. ${ }^{161}$ No significant competitor has entered the market since Ticketmaster's acquisition of Ticketron in $1991 .^{162}$ Moreover, new venues capable of holding large-scale entertainment events seldom emerge, and existing venues are available for new contracts only infrequently. ${ }^{163}$ These facts indicate substantial foreclosure with probable immediate anticompetitive effects-the essential basis for an attack on an exclusivity contract. ${ }^{164}$

The impact of foreclosure in this industry is apparent. Not only have existing competitors been driven from the market, but new competitors also have failed to enter the market. Moreover, Ticketmaster has raised its service charges on tickets to exorbitant amounts, thus directly injuring the consumer. ${ }^{165}$ At the same time, the foreclosure effects have left consumers without an alternative to paying these inflated prices. These results belie any theoretical argument that foreclosure as a result of exclusive dealing never can occur. ${ }^{166}$

\section{Ease of Entry}

The Federal Trade Commission in Beltone Electronics Corporation $^{167}$ described how exclusive dealing arrangements can erect barriers to entry: "We are concerned primarily with restraints that may increase the costs of entry and reduce opportumities for new entrants to distribute their products [or to obtam suppliers], makmg it more difficult to open up less-than-competitive markets."168

161. See U.S. Healthcare, Inc. v. Healthsource, Inc., 986 F.2d 589, 596 (1st Cir. 1993) (undertaking similar analysis in determining possible impact of exclusive contracts between HMO and physicians).

162. See Stern, supra note 20 , at 11 .

163. See U.S. Healthcare, 986 F.2d at 596 (noting that continual entrance into the market by new doctors with immediate need for patients served as indicator that foreclosure did not impair the ability of new HMOs to operate). With exclusive contracts generally lasting three to five years, one-third to one-fifth of the market would open annually; this, however, is not necessarily sufficient to relieve the clog on competition that such exclusivity creates. See infra text accompanying notes 180-89.

164. See infra text accompanying notes 180-89.

165. See Stern, supra note 20 , at $354-55$.

166. See supra notes $53-54$ and accompanying text.

167. 100 F.T.C. 68 (1982).

168. Id. This case deals with distributor exclusivity; for purposes of this Note, however, distributor exclusivity may be analyzed imder the same principles as supplier exclusivity. See supra note 27. 
Some commentators would ignore the impact of entry barriers altogether im antitrust analysis. ${ }^{169}$ The better view, however, recognizes that entry barriers effectively can create unreasonable restraints on competition. Barriers erected by the exclusive dealing arrangements in the ticketing service industry must be analyzed with a view toward actual competitive effects.

The relevant inquiry, then, is whether and to what extent the foreclosure created by exclusive dealing raises barriers to entry. ${ }^{170}$ Several barriers to entry exist in the ticketing distribution industry. First, existing competitors have been forced to seek new venues and promoters; the lack of large-scale competitors indicates that these coinpamies have either shifted to sinaller-scale venues in order to procure distribution contracts or abandoned the market entirely. Second, potential competitors face the difficult task of attracting venues and proinoters that have dealt with Ticketmaster extensively over a long period of time. ${ }^{171}$ Moreover, Ticketmaster's practice of providing dealers and promoters with additional financial incentives-in the form of percentages of service charges paid by consumers- to enter into exclusive dealing contracts has lured suppliers away from other distributors and discourages potential competitors from attempting to enter the market. Exclusive dealing therefore appears to have created severe barriers to entry into the market.

Theoretically, Ticketınaster's conduct can be justified as pursuing legitimate busmess practices, and any resulting entry barriers may be characterized simply as the natural, reasonable results of such practices. Potential competitors will find entry difficult simply because Ticketınaster is efficient, has created significant economies of scale, and possesses valuable computer and communications equipment, a sturdy reputation, and greater experience in the industry. Arguably, these entry barriers are inherent im the nature of competition. ${ }^{172}$ However, the barriers Ticketmaster has created

169. " $[\mathrm{I}] \mathrm{t}$ is demonstrable that barriers of the sort these commentators and jurists believe they see do not exist. They are ghosts that inhabit antitrust theory." Bork, supra note 7 , at 310 .

170. Beltone, 100 F.T.C. at 184.

171. The complaint in a recently filed suit, MovieFone, Inc. v. Ticketmaster Corp., alleges that "[b]arriers to entry into teleticketing for [popular live events that the industry expects will sell out] are high because experience, reputation for reliability, and substantial specialized computer/communication capability are necessary." reprinted in 68 Antitrust \& Trade Reg. Rep. (BNA) 449, 449 (Apr. 6, 1995).

172. See BORK, supra note 7 , at 311 . 
in enforcing its exclusive dealing contracts appear to be, in Robert Bork's terms, "artificial clogs upon competition" that are "not forms of superior efficiency,"173 and hence, undeserving of protection from antitrust hability. ${ }^{174}$ Ticketmaster creates artificial barriers to entry through the very terms of its exclusive dealing contracts. By providing financial incentives to venues and promoters without cost justifications, Ticketmaster maintains exclusivity arrangements and artificially bars entry without engaging in any efficiency-enhancing conduct. Moreover, one complainant has alleged that the corporation engages in economically irrational conduct, enforcing its contracts to the extent that it sacrifices shortterm profits to further exclusionary goals. ${ }^{175}$

Lower courts that have addressed ease of entry into the market also note that high entry barriers are imdications that incumbent firms will exploit their market power and raise prices above the competitive level. ${ }^{176}$ Conversely, when a firm actually raises prices significantly and no new entry appears, this result signals that entry barriers are currently in place. Ticketmaster has raised its prices repeatedly in the absence of threats from any other competitors. ${ }^{177}$ The Federal Trade Commission also has recognized that one important factor in analyzing anticompetitive effects is the actual entry of other coinpetitors into the inarket. ${ }^{178}$ The

173. Id.

174. Under this analysis, even a Chicago School legal theorist may be inclined to view Ticketmaster's exclusive contracts as violations of the Sherman Act. See supra notes 7-10 and accompanying text.

175. The complaint filed against Ticketmaster by the band Pearl Jam alleges that the corporation organized a group boycott agamst the group when it sought to distribute its own tickets for concerts at venues with which Ticketmaster had exclusive contracts. The complaint argues:

Ticketmaster's insistence that promoters strictly abide by the exclusivity provisions in their agreements has effectively frozen Pearl Jam out of distributimg tickets to its own concerts. ... [Ticketmaster's economically irrational actions are] demonstrated by Ticketmaster's position-reported in the March 25, 1994 memorandum by NACPA's executive director-that. . . . Ticketmaster is willing to forego the profits it would earn by distributing a portion of tickets to [the] concerts in order to discipline Pearl Jam and mip in the bud what it fears might become the widespread nse of alternative means of distribnting tickets by other performers.

Memorandum from Pearl Jam to the Antitrust Div. of the U. S. Dep't of Justice Concerning Anticompetitive Actions Engaged in by Ticketmaster Holdings Group Ltd. 12 (May 6, 1994) (on file with author).

176. See Interface Group, Inc. v. Mass. Port Auth., 816 F.2d 9, 11 (1st Cir. 1987).

177. See Stern, supra note 20 , at $350,377$.

178. See In re Beltone, 100 F.T.C. at 210. 
Federal Trade Commission analyzed ease of entry into the relevant market in Beltone: "[Other] firms have recently entered the market or grown vigorously, in part at the expense of the older firms. The new entrants have experienced little difficulty in finding [suppliers or] distributors."179 No similar entry by computer ticketing companies witl Ticketmaster's capability to have an impact on national or regional markets lias occurred, indicating that the exclusive contracts have erected high entry barriers that potential coinpetitors lave not been able to overcome.

\section{Duration}

The duration of the contracts is an important factor in assessing the foreclosure effects of exclusivity. Exclusivity contracts witl short terms and specific provisions for short notice of termination generally are presumed to be lawful. ${ }^{180}$ The rationale for this position is that when contracts are either short-term or terminable on short notice, vigorous competition for the contracts emerges when contracts expire and terms must be renegotiated. Longer contracts are more likely to tie up the market for unreasonable periods, making it difficult for actual or potential competitors to secure the supphiers needed to compete effectively. ${ }^{181}$

The Justice Department has identified the potential dangers of long-term exclusive contracts:

In general, the longer the term of a vertical restraint (especially if such a term cannot be justified by the need to encourage investment) the more likely it is that the restraint is exclusionary .... [A]n exclusionary effect is more likely where large suppliers' [or distributors'] exclusive dealing contracts have very long terms and assess major financial penalties against dealers who change suppliers [or distributors]. ${ }^{182}$

179. Id.

180. Roland Machinery Co. v. Dresser Industries, Inc., 749 F.2d 380, 395 (7th Cir. 1984) (noting that contracts terminable in less than one year are presumed to be lawful).

181. See Twin City Sportservice v. Charles O. Finley \& Co., 676 F.2d 1291, 1304 (9th Cir.), cert. denied, 459 U.S. 1009 (1982). The court found that the magnitude and considerable length of the defendants' exclusive contracts had a detrimental effect on competition: "[T]hey have locked up a large portion of the concession franchise market for many years, placing a significant amount of potential concession business beyond the grasp of any competitors." Id. The court further noted that the length of the contracts was unnecessary to recapture investments made in the contracts. Id.

182. Vertical Restraints Guidelines, 50 Fed. Reg. 6,263, 6,271; see also U.S. Healthcare, Inc. v. Healthsource, Inc., 986 F.2d 589, 596 (1st Cir. 1993) (recognizing that 
No standard rule dictates how long a contract term may endure legally or how long a termination requirement is permissible; instead, courts examine the surrounding business environment, and consequently, the actual effect the contracts have on competition. "[I]t is the totality of reasons for such a term, and its actual impact on competition, that are decisive." 183 Of course, the longer the term of an exclusive contract, the more closely courts and law enforcement agencies should scrutinize it.

Ticketmaster's contracts reportedly have terms of three to five years. ${ }^{184}$ These terms are substantial; courts have invalidated exclusive contracts with lesser duration requirements. ${ }^{185}$ Ticketmaster might argue that the expense of securing the contracts and their capital investment in the business requires longer terms for the contracts. However, these business justifications are not persuasive in hight of the contracts' severe anticompetitive effects. The absence of any effective competitors in the industry is evidence that the long-term nature of the contracts has contributed to an "actual, not potential 'clog' on competition." ${ }^{186}$ No evidence suggests that shorter-term contracts would not protect Ticketmaster's investment to an equal degree while restraining competition to a lesser extent.

Terminability of contracts is also a factor in evaluating the reasonableness of exclusive dealing arrangements. Theoretically, contracts that are easily terminated present less of a threat to effective competition. Some courts have found exclusive contracts terminable in less than a year to be presumptively lawful. ${ }^{187}$ However, the First Circuit has ruled that terminability, even when

even a contract terminable on 30 days notice may have anticompetitive effects if a reimbursement penalty were imposed on doctors who moved from exclusive to nonexclusive status).

183. Tri-State Rubbish, Inc. v. Waste Mgmt., Inc., 998 F.2d 1073, 1080 (1st Cir. 1993).

184. See Stern, supra note 20 , at 353 ; see also supra note 25 .

185. See, e.g., L. G. Balfour Co. v. FTC, 442 F.2d 1, 23 (1971) (upholding the Federal Trade Commission's order invalidating 3-year exclusive dealing contracts with high schools as anticompetitive and unfair methods of competition); Zap Professional Photography, Inc. v. McCluney, 663 So. 2d 922 (Ala. 1995) (applying state antitrust laws to declare exclusive dealing contracts to be unlawful exercise of monopoly power and restricting company's two-year exclusive dealing contracts to one-year terms) (citing United States v. Grinnell Corp., 384 U.S. 563 (1966)).

186. Stern, supra note 20 , at 377 .

187. See, e.g., Roland Machinery Co. v. Dresser Industries, Inc., 749 F.2d 380, 395 (7th Cir. 1984). 
possible with short notice, will not reverse anticompetitive results in the market. ${ }^{188}$ In U.S. Healthcare, the First Circuit noted that even a thirty-day terminability clause could have the effect of frustrating a coinpetitor's efforts to have access to the services of doctors that are essential to the function of the competitors' business. ${ }^{189}$ Therefore, even if Ticketmaster's contracts permit termination on relatively short notice, the contracts are not necessarily lawful.

\section{E. The Final Analysis}

If courts closely scrutinize each of these factors in the context of the computerized ticketing industry, they should conclude that exclusive dealing has harmed competition and that public intervention is required to halt current unlawful business practices. The exclusive dealing arrangements undertaken by Ticketmaster and contracting venues and promoters foreclose a substantial portion of the relevant inarket by imposing excessive duration terms and creating significant artificial barriers to entry. Neither potential nor actual coinpetitors have succeeded in dissipating Ticketınaster's market power, and the practical results are evident: Consumers have been forced to pay inflated prices for tickets to entertainment events. The coinplete failure of inarket forces theinselves to cure any anticompetitive effects requires that the law intervene and restore healthy competition to the industry.

Ignoring the practical effects and applying strict economic theory, however, would allow a court or enforcement agency to overlook these severe anticompetitive effects. Theoretically, for example, Ticketmaster's exclusive dealing contracts serve primarily as a means to a legitimate business end: reduction of costs through the creation of scale economies, decreased transaction costs, and the elimination of free riders. In reducing its costs, Ticketmaster should be able to operate more efficiently and distribute tickets to the ultimate consumer at a lower charge. In reality, however, Ticketmaster consistently has raised the service charges it adds to the price of a ticket. One would expect this sharp imcrease in prices to encourage new entry into the industry; new entrants could price slightly below Ticketmaster's prices and still make a

188. See U.S. Healthcare, Inc. v. Healthsource, Inc., 986 F.2d 589, 596 (1st Cir. 1993).

189. Id. 
substantial profit. Yet no new competitors have emerged because Ticketmaster's strict enforcement of its exclusivity agreements and the long-term nature of the contracts tie up existing venues and promoters and deny new competitors the essential supply that they need to operate. In the final analysis, Ticketmaster's proffered business justifications are weak, if not entirely misleading.

In the absence of legal intervention, Ticketmaster will continue to eliminate actual and potential competitors from the imdustry and to raise service charges for the consumer, with no check on the exercise of its market power. This result imdicates that in order to further the goals of antitrust law, courts must scrutinize the competitive effects of exclusive dealing closely $m$ any situation in which a dominant firm utilizes long-term exclusive dealing contracts, market foreclosure appears to be substantial, and anticompetitive effects are the likely result.

\section{CONCLUSION}

Antitrust is by no ineans a static area of law. Instead, it contimuously evolves in correlation with changing social and pohtical views. This result camot be avoided; antitrust law is grounded in a number of competing and ever-changing forces, includimg economic theory, social pohcy, pohtical pressures, and judicial sentiment. At any given moinent, therefore, predicting the next direction antitrust law will follow proves to be a difficult task.

The 1980s inarked an era of few civil antitrust cases filed by the government, and fewer verdicts against antitrust defendants. ${ }^{190}$ This result was dependent on a number of factors, including the emergence of the "new economic learning," the influence of powerful interest groups, and lower funding and staffing of the Federal Trade Commission and the Antitrust Division of the Department of Justice. The 1990s, however, have witnessed a change in policy. The Departinent of Justice has announced its intention to investigate and ultimately prosecute companies whose busimess practices violate the antitrust laws. ${ }^{191}$ Moreover, both the Justice Department and the Federal Trade Commission will place a particular emphasis on investigating vertical restramt cas-

190. See Donald L. Flexner \& Mark A. Racanelli, State and Federal Antitrust Enforcement in the United States: Collision or Harmony?, 9 CONN. J. INT'L LAW 501, 508 (1994).

191. See supra notes $110-15$ and accompanying text. 
es, ${ }^{192}$ which have been treated leniently in previous years. The Supreine Court as well has indicated its willingness to deal with vertical restraint cases in a inore meaningful nuanner. ${ }^{193}$

This new trend indicates that coinpamies that have no major rivals and control a large percentage of the market will be scrutinized carefully both by public enforcement agencies and by the judiciary. Companies charged with antitrust violations should not, and hopefully will not, succeed simply by asserting a defense based on economic theory and not grounded in economic fact. For dominant incumbent firms, simple recitation of the potential procoinpetitive effects of exclusivity arrangements should no longer provide insulation from enforcement of the antitrust laws. Careful scrutiny of exclusive dealing will serve both the letter and the spirit of the federal antitrust laws.

192. See Withdrawal of Vertical Guidelines Is Discussed as Positive Step for Law, News \& Comment, 65, Antitrust \& Trade Reg. Rep. (BNA) 434, 435 (1993) ("Finding vertical cases is a priority of the [FTC's Burean of Competition]. . . . revocation of the [DOJ's Vertical Restraint Guidelines] will 'make it easier for us' to find them.").

193. See supra notes $106-09$ and accoinpanying text. 